\title{
The Quality Life of Children with Attention / Hyperactivity Disorder (ADHD) in Type C Special Schools in Bandung Indonesia
}

\author{
Adelse Prima Mulya ${ }^{1 *}$; Desy Indra Yani ${ }^{2}$; Helwiyah Ropi ${ }^{3}$ \\ ${ }^{1 *), 2,3}$ Universitas Padjadjaran
}

\section{ARTICLE INFO}

Article history:

Received January 17, 2019

Revised May 18, 2019

Accepted May 19, 2019

\section{Keyword:}

School-Aged Children

Attention Defisit Hyperactivity Disorder Quality of Life

\section{*) corresponding author}

Nursing Faculty, University of Padjadjaran Jl. Raya Bandung-Sumedang Km. 21, Jatinangor Sumedang 45663

Phone (+6222) 7795596

Email: adelse@unpad.ac.id

DOI:https://doi.org/10.30604/jika.v4i1.166

\begin{abstract}
A B S T R A C T
Attention Deficit Hyperactivity Disorder (ADHD) is a behavioral disorder characterized by attention deficit disorder, impulsive behavior, accompanied by excessive activity that is not in accordance with his age in childhood. ADHD can affect the quality of life of children. This study aims to describe the quality of life of ADHD children in SLB type $C$, Bandung. The design of this study is descriptive. The research subjects were 63 families who had ADHD children with an age range of 8-12 years who attended school in 5 types C SLB Bandung. Sampling using the total sampling technique with an inventory questionnaire, namely the QoL (PedsQL) questionnaire. Data analysis using descriptive analytics. The results showed that more than half of the quality of life of ADHD children was classified as poor. The quality of life of children with $A D H D$ is very important because it contains various aspects of their lives, both from their physical, emotional, social, and school activities. This research clarifies quantifying the quality of life of ADHD children starting from physical, emotional, social and school functions. From these explanations, it is expected that in the part of the quality of life for ADHD children to experience deficiencies, and which parts can be improved and care and attention need to be improved.
\end{abstract}

This is an open access article under the CC-BY-SA license.

\section{INTRODUCTION}

Common problems that often hinder the development of school-age children are Attention Deficit Hyperactivity Disorder (ADHD) or Attention Deficit / Hyperactivity Disorder (ADHD). ADHD is a behavior disorder characterized by inat-tentiveness, impulsivity, and can be accompanied by excessive activity (over-activity / hyperactivity) that is not in accordance with age in childhood (American Psychiatric Association / APA, 2000). 
Children with ADHD are increasingly common in the community, where the incidence is increasing especially in schoolage children. The prevalence of ADHD in school-aged children worldwide is around $3 \%-10 \%$, although prevalence rates vary substantially (Polanczyk, de Lima, Horta, Biederman, \& Rohde, 2007). The prevalence of ADHD in East Asian countries, shows a similar prevalence between West and nonWest, which is around $8.1 \%$ to $8.6 \%$ (Gau, Chong, Chen, \& Cheng, 2005; Takahashi, Miyawaki, Suzuki, Mamoto, Matsushima, Tsuji , \& Kiriike, 2007). In Indonesia the number of occurrences is still unclear, even though this disorder appears to be quite a lot and often found in preschoolers and schoolage (Judarwanto, 2007). However, in a study by Wihartono (2007), the prevalence of ADHD in West Java Province, especially in the city of Bandung for elementary school students and special needs schools was found at $2.70 \%$.

The impact of the three combinations of ADHD symptoms including symptoms of hyperactivity, inertiveness and impulsivity that can lead to child development becoming abnormal, making it difficult for children with ADHD to achieve in school. Hyperactive behavior makes ADHD children have difficulties when in social institutions (Vaughan, Roberts \& Needelman, 2009). Many of the ADHD children have difficulties in the school environment, often having problems in the forms of discipline or academic difficulties (Weyandt \& DuPaul, 2006).

This condition certainly causes suffering and obstacles for children in carrying out their daily functions. Various other disorders that can occur in ADHD children such as a lack of confidence in children, interference with interacting with peers, family and also disturbing children's readiness to learn and in a whole way will make a decrease in the quality of life of children (Escobar, Soutullo \& Hervas, 2005 ; Nijmeijer, Minderaa, \&
Buitelaar, 2008; Varni \& Burwinkle, 2006; Strine, Lesesne, \& Okoro, 2006).

The quality of life of ADHD children is inseparable from several factors that influence it. According to Jeanne, Landgraf, Rich, \& Rappaport (2002) the quality of life factors for ADHD children can be seen from the impact caused or AIM (ADHD impact module) including children's health status, frequency of "successful" experiences of children with parents at home, parent assessment (child health, child discipline, parenting for children, and child behavior), the time of diagnosis of the child, how long the child gets treatment, and the role of the family in supporting ADHD children. Other factors that influence the quality of life of children with ADHD include demographic factors, family support, clinical, physical, emotional, family and social anxiety (Riley, 2006; Wehmeier, Schacht, \& Barkley, 2010; Sánchez, Cortés, Carlos, Moren, 2012 ; Theole, 2010).

Support and participation of health workers are needed for improving the quality of life of ADHD children, one of which is school health-based community nursing. School health-based community nursing not only pays attention to the quality of life of schoolchildren but takes care of all aspects, both school, family and society as a whole and organized. According to the Centers for Disease Control and Prevention (2011); Murray, Low, Hollis, Cross, \& Davis (2007), community nursing responsibilities for school health include; health education, physical health education, health services, nutrition services, counseling, psychological and social services, healthy school environment services, health promotion of teacher staff in schools, and community and family involvement.

But the existence of community-based community health nurses is still not active in Indonesia, especially in the city of Bandung. Community nurses fully still do not pay attention to school health, especially the health of schools with special needs. 
Community nurses still tend to provide comprehensive primary care services to various age groups.

Starting from the statements above, in Indonesia no research has been conducted on the quality of life of children with GPPH. Although research on the quality of life of ADHD children has been carried out in America and Europe, similar research is also important in Indonesia because it sees the demographic factors of these countries very much different from the demographic conditions in Indonesia. For this reason, the authors are interested in conducting this research, with the aim of this study, namely to find out an overview of the quality of life of ADHD children in Type C Special Schools in Bandung.

\section{METHOD}

The research activity was carried out for 30 days including collecting data through questionnaires and interviews in 5 SLB C Bandung City. This research is a descriptive study that aims to explain the picture of the quality of life of children with ADHD. The research design used was a cross sectional study.

The sample in this study were families who had school-age children who had ADHD with inclusion criteria including; 1) school age children aged 8-12 years who have a diagnosis of ADHD by a psychiatrist; 3) attending education at SLB C in Bandung; 4) living at home with biological parents; 5) parents are willing to follow the research process; 6) ADHD children owned by families do not experience other physical disabilities such as blindness, mute, paralyzed and so on. Sampling uses a total sampling system with a total sample size of the population of 63 respondents spread over 5 type C SLBs in the city of Bandung.

The child's life quality instrument for ADHD was measured using the Pediatric Quality of Life Inventory (PedsQL) Generic Core version 4.0. The questionnaire is composed of 23 statements consisting of: 1) Physical function 8 statements; 2) Emotional functions 5 statements; 3) Social functions 5 statements; and 4) School functions 5 statements. This questionnaire consists of answer choices using a Likert scale (never, sometimes, often and always). The answer is never worth 1, sometimes worth 2 , often worth 3 and always worth 4 for positive statements while negative questions have the opposite value. All answers will be summed with the total total score. The highest score is 92 and the lowest score is 23 . The quality of life of ADHD children is stated to be good if the total score of quality of life of ADHD children has a range of values of 47-92 and is declared less good with a range of values 2346.

This questionnaire has been tested for validity and reliability testing with Alpha Cronbach's equal to (0.90). The questionnaire used is an inventory questionnaire in English, so the translation has been done first into Indonesian and the translation is back into English (back translation) which has been carried out and has been examined by two lecturers who are competent in their field. From the results of the back translation, there is no difference in meaning between the transition between English-Indonesian and Indonesian-English, so this questionnaire can be used.

This study uses univariate analysis which aims to explain or describe each research variable in this case is the quality of life of ADHD children.

\section{RESULTS AND DISCUSSION}

This research was conducted on families who have school-age children who have ADHD who attend Special C Schools in Bandung City. The characteristics of the respondents are as follows: 
J urnal Aisyah: J urnal Ilmu Kesehatan, 4(1), J uni 2019, - 66

Adelse Prima Mulya; Desy Indra Yani; Helwiyah Ropi

Table 1

Quality of Life of ADHD Children Based on Score Criteria $(\mathrm{N}=63)$

\begin{tabular}{lcccc}
\hline \multicolumn{1}{c}{ Variable } & Criteria Score & Score of Min-Max & Mean & SD \\
\hline Quality of life : & $23-92$ & $35-64$ & 44,6 & 9,3 \\
& & & & \\
Physical function & $8-32$ & $8-29$ & 19,4 & 5,4 \\
Emotional function & $5-20$ & $5-17$ & 9,6 & 4 \\
Social function & $5-20$ & $5-17$ & 8,6 & 3 \\
School function & $5-20$ & $5-16$ & 9,8 & 3 \\
\hline
\end{tabular}

Based on table 1 above, it is known that the functions 9.6 social functions 8.6 and school average overall quality of life is 44.6 with an functions.

average physical function of 19.4 emotional

Table 2

Quality of Life of GPPH Children Based on Categorization ( $N=63$ )

\begin{tabular}{lcc}
\hline \multicolumn{1}{c}{ Variable } & Frequency (f) & Percentage (\%) \\
\hline Quality of Life of Children with ADHD: & 21 & 33,3 \\
Good & 42 & 66,7 \\
Not good & & Q \\
\hline
\end{tabular}

Based on table 2, it is known that more than half $(66.7 \%)$ of the quality of life of children with ADHD are poor $(\mathrm{N}=63)$.

Quality of life is an important aspect of health that describes the ability of individuals as a whole both physically, emotionally, socially and environmentally (school).

This study looked at the quality of life of ADHD children in terms of children's ability to do things in various aspects including physical, emotional, social and school functions. Quality of life was assessed using a questionnaire filled in by parents of children who all used negative statements regarding physical, emotional, social and school functions. If the child gets a higher score with a maximum limit of 92 then the quality of life of the child is said to be good, conversely if the family gets the lower value nearing the minimum limit of 23 points, the quality of life of the child is declared to be poor.

Based on the results of the study, the quality of life of ADHD children more than half $(66.7 \%)$ was categorized as poor and the rest (34.3\%) were categorized as good. The average results of total quality of life scores obtained by children are 44.6 with min-max values (35-64). The results of the total score of quality of life include several dimensions including physical function with an average value of 19.4. Emotional function has an average value of 9.6. Then social functions with an average value of 8.6 and school functions with an average score of 9.8. The overall dimensions of the quality of life of ADHD children with social function dimensions have the lowest average, meaning that the quality of life of ADHD children is still lacking in terms of social function.

The results of this study are similar to those of Jafari, Ghanizadeh, Akhondzadeh, \& Mohammadi (2011), measuring the quality of life of children with ADHD can use Peds QL. The results of this study obtained a reliability analysis value of 0.85 and showed that the quality of life of children with ADHD was lower than children who had cancer. Seid, Varni, Segall, \& Kurtin (2004) Cenederung GPD children have low quality of life and need immediate intervention. Sánchez's research, Cortés, Carlos, Moreno, \& Poblano (2012) children's emotional factors tend to cause the quality of children to decline. 
According to Ridley \& Young (2002) healthrelated quality of life / HRQOL describes the views of individuals or families about the health level of the individual after experiencing an illness and getting a form of management. Health-related quality of life describes a multidimensional healthy and functional component such as physical, emotional, mental, social and behavior that is perceived by patients or other people around the patient (parent or caregiver).

The quality of life of ADHD children is depicted with feelings of happiness and the good condition possessed by ADHD children including physical, emotional, family, social, and achievement in school as well as decreasing incidence of childhood illness (Loonen, Derkx and Otley, 2001; Richardson, Griffiths, Miller, \& Thomas, 2001; and Ware \& Dewey, 2000). The quality of life of ADHD children is very important to be known by a community nurse. King \& Hinds (2011) stated that the perspective of quality of life is very relevant to the realm of nursing. Padilla \& Grant (1985) in King \& Hinds (2011) quality of life refers to how to make life more valuable, this connotation with aspects of caring in the realm of nursing, because nursing not only pay attention to survival and decrease client pain, but more to aspects overall to clients including meaningful life (quality of life).

Nursing is the practice of "caring" in which nurses help maintain and promote client health, including improvement in function. Through data on the quality of life of clients, nurses will be more able to provide assistance to clients in terms of providing care, improving health and providing motivation in dealing with the problems they face in order to increase their sense of comfort (happiness) in dealing with their illness.

Normally children with health problems especially mental health and behavior will tend to experience a decrease in their quality of life. Biologically, the child has a disturbance in the cerebral system, this is what really triggers the behavior of children so that children are difficult to control their behavior. As a result, children find it difficult to socialize, achieve achievements and even experience emotional disturbances.

\section{CONCLUSIONS AND RECOMMENDATION}

From the results of the renewal of this research, it shows that from several components of the quality of life of ADHD children, it turns out that the less fulfilled are the emotional, social and school functions. Seen to have a mean range that is less than half the total score. For this reason, it is hoped that the future solution will be to meet these needs for the realization of the quality of life of optimal ADHD children.

The quality of life of children with ADHD is very important, because it contains various aspects of their lives both from their physical, emotional, social, and school activities. This research clarifies quantitatively the quality of life of ADHD children starting from physical, emotional, social and school functions. From this explanation, it is expected that in the part of the quality of life for ADHD children to experience shortcomings, and which parts can be repaired and need to be improved care and attention.

This research is considered to be imperfect for that it requires special developments in experimental research to improve the quality of life of ADHD children. This study can help as a reference for future experimental research so that when treated, it will be right on target.

\section{REFERENCES}

American Psychiatric Association. (2000). Diagnostic and Statistical Manual of Mental Disorders. 4th, Text Revised. Washington, DC: American Psychiatric Press, Inc. 
Centers for Disease Control and Prevention (CDC). (2011). School health guidelines to promote healthy eating and physical activity. MMWR. Recommendations and reports: Morbidity and mortality weekly report. Recommendations and reports/Centers for Disease Control, 60(RR-5),1. https://www.cdc.gov/nchs/data/hus/hus 11.pdf

Escobar, Soutullo C.A.Hervas A. (2005). Worse quality of life for children with newly diagnosed attentiondeficit/hyperactivity disorder, compared with asthmatic and healthy children. Pediatrics. 13, 234-250 https://doi.org/10.1542/peds.2005$\underline{0386}$

Gau, S. S., Chong, M. Y., Chen, T. H., \& Cheng, A. T. (2005). A 3-year panel study of mental disorders among adolescents in Taiwan. American Journal of Psychiatry, 162, 13441350.https://doi.org/10.1176/appi.ajp.1 62.7 .1344

Jafari, P., Ghanizadeh, A., Akhondzadeh, S., \& Mohammadi, M. R. (2011). Healthrelated quality of life of iranian children with attention deficit/hyperactivity disorder. Quality of Life Research, 20(1), 31-6. doi: http://dx.doi.org/10.1007/s11136-0109722-5

Judarwanto, W. (2007). Penatalaksanaan attention deficit hyperactive disorders pada anak. Tesis. Universitas Gajah Mada

King, C. R., \& Hinds, P. S. (2011). Quality of life: From nursing and patient perspectives. Jones \& Bartlett Publishers.

Loonen, H. J., Derkx, B. H., \& Otley, A. R. (2001). Measuring health-related quality of life of pediatric patients. Journal of pediatric gastroenterology and nutrition, 32(5), 523-526. https://www.ncbi.nlm.nih.gov/pubmed/ $\underline{11429510}$

Murray, N. G., Low, B. J., Hollis, C., Cross, A. W., \& Davis, S. M. (2007). Coordinated school health programs and academic achievement: A systematic review of the literature. Journal of School Health, 77(9), 589600. https://doi.org/10.1111/j.17461561.2007.00238.x

Nijmeijer JS, Minderaa RB, Buitelaar JK. (2008). Attention-deficit/ hyperactivity disorder and social dysfunctioning. Clin Psychol Rev;28:692-708. https://doi.org/10.1016/j.cpr.2007.10.0 $\underline{03}$

Polanczyk, G., de Lima, M. S., Horta, B. L., Biederman, J., \& Rohde, L. A. (2007). The worldwide prevalence of ADHD: A systematic review and metaregression analysis. American Journal of Psychiatry, 164, 942-948. https://doi.org/10.1176/aip.2007.164.6. $\underline{942}$

Richardson, G., Griffiths, A. M., Miller, V., \& Thomas, A. G. (2001). Quality of life in inflammatory bowel disease: a cross-cultural comparison of English and Canadian children. Journal of pediatric gastroenterology and nutrition, 32(5), 573-578. https://www.ncbi.nlm.nih.gov/pubmed/ 11429510

Ridley S, Young D. (2002). Classification and measurement problems of outcomes after intensive care. In : Griffiths RD, Jones $\mathrm{C}$, eds. Intensive care after care Oxford : ButterworthHeinemann, 142-5.

Riley, A. W., Spiel, G., Coghill, D., Döpfner, M., Falissard, B., ... Lorenzo, M. J. (2006). Factors related to healthrelated quality of life (HRQoL) among children with ADHD in europe at entry into treatment. European Child \& Adolescent Psychiatry, 15, I38-45. doi: 
http://dx.doi.org/10.1007/s00787-006$\underline{1006-9}$

Strine TW, Lesesne CA, Okoro CA. (2006). Emotional and behavioral difficulties and impairments in everyday functioning among children with a history of attentiondeficit/hyperactivity disorder. Prev ChronicDis,3:A52.https://www.ncbi.nl m.nih.gov/pmc/articles/PMC1563970/

Theule, J. (2010). Parenting stress in families to quality of life children with ADHD. Dissertation Doctor of Philosophy. University of Toronto. http://ebx.sagepub.com/content/early/2 $\underline{012 / 01 / 24 / 1063426610387433}$

Varni JW, Burwinkle TM. (2006). The PedsQL as a patient-reported outcome in children and adolescents with Attention-Deficit/Hyperactivity Disorder: A population-based study. Health Qual Life Outcomes,4:26. https://doi.org/10.1007/s11136-005$\underline{1388-\mathrm{Z}}$

Vaughan, B.S., H.J. Roberts., \& H.Needelman, (2009). Current medications for thetreatment of ADHD. Psychology in the Schools,
46(9),846-856.

https://doi.org/10.1002/pits.20425

Ware, J. E., Kosinski, M., Dewey, J. E., \& Gandek, B. (2000). SF-36 health survey: manual and interpretation guide. Quality Metric Inc. Lincoln. https://trove.nla.gov.au/work/1043483 1

Wehmeier, P. M., Schacht, A., \& Barkley, R. A. (2010). Social and emotional impairment in children and adolescents with ADHD and the impact on quality of life. Journal of Adolescent Health, 46(3), 209-217.

https://doi.org/10.1016/j.jadohealth.2009.09. $\underline{009}$

Weyandt, L. L., \& DuPaul, G. (2006). ADHD in college students. Journal of Attention Disorders, 10 (1), 9-19. https://doi.org/10.1177/108705470528 $\underline{6061}$

Wihartono, W. (2007). Faktor Risiko Attention Deficit/Hyperactivity Disorder pada murid sekolah SD di Kecamatan Banguntapan Kabupaten Bantul D.I. Yogyakarta: Artikel Penelitian. Berkala Kesehatan Klinik. 2007;VIII(2):73-81. 